\title{
THE FRONT LINE
}

\author{
How to save the Universe.
}

\section{BY SYLVIA SPRUCK WRIGLEY}

$\mathrm{F}$ irst of all, I want you to forget every single word that they told you at the recruiting office. No, just stop, I don't need to hear it. It's all lies.

Stand right up here with me and take a look around. This is the front line. No, that is not a euphemism. War's not normally neat with straight lines and easy-to-understand strategies, but here we have a line. It's that trench right there. Don't get too close to the edge.

The Sporians disintegrate about four of our people a day. Your ship came in with 10 crates of supplies and 500 raw recruits. You do the maths. Don't make friends.

Listen. We don't need you to wear uniforms or learn to shoot a gun or do anything but be here and drink cod liver oil and die. That's the reality.

Nah, I'm joking. It's not actually cod liver oil. It's worse. It smells like something the dog shat out and tastes like rancid butter. You'll learn to ignore your gag reflex and force it down, just like the rest of us.

That's one of the few things we know. We don't know how to fight them. We don't even know if they are intelligent. But every time we give up and leave the rock to them, they move in closer. Your job is to stand around like you might want to get infected. Don't get infected. That's it.

You won't know if you get infected. You just zombie off looking for high ground and a few hours later, a stalk grows out of your head and explodes. Neon orange spores scatter everywhere, looking for a new home. See, that's why we like this trench right here. You see one of your mates acting like a zombie, push him in. Fast.

Truth is, when we first got the reports from Earth, we just quarantined it off. There was barely anyone left there anyway, right? But then, suddenly, we're getting orange mould patches on Mars. Military went in

\section{$\rightarrow$ NATURE.COM}

Follow Futures:

@ @NatureFutures

f go.nature.com $/ \mathrm{mtoodm}$ that time, bombed the planet with every fungicide known to man. That's when we discovered the oil. The Sporians don't like it. No, we don't know why. We don't know shit about them other than right here, right now, we're holding them at this trench. And we know that if they have a choice between someone who's been drinking the anti-fungal oil and some

populated 'stroid is only $2 \mathrm{AU}$ from here, a hell of a lot closer than Mars. That settlement's not seen a single patch of mould. And they won't, so long as dumb recruits like you keep coming.

The oil's the only thing we've found that even makes 'em wince. It won't help if you're the last one standing, but for now? Drink the oil. Tell the guy next to you not to bother. Try not to get infected. Push anyone infected down into the deep as fast as you goddamn can.

I'm sorry to be the one to tell you, but that's our war. Stand guard at the top of a trench and try to last more than a week while brighter minds search for a way to fight back.

Right, now get to work. Start unpacking those crates and I'll tell you the good news. Yeah, it's not much, but there is good news.

Number 1 . The infected seem like they die happy. I've seen more than my fair share. Hallinan didn't talk or anything but he got this real peaceful look. Patel's last word was: "Finally." Steinberg just stared at the sky and grinned. So, here's my thought: maybe the Sporians are God. Maybe this is the second coming. Maybe you are all about to get saved.

I don't know that it's true, but it helps to get me through the night.

Number 2. Half of those crates you are unloading are full of gin. We don't need to stay sober, we just need to stay here. There's no way off this rock so we might as well have a party. Might even find some cocktail sticks, if you're lucky.

fussy idiot who hasn't, they'll infect the fussy kid every time.

Anyway, we gave 'em Mars, too. G Council just said, fine, have a planet. Wrote it off.

And it didn't work. A few weeks later, orange flecks. The Sporians start showing up here in the belt. There're no transports. Not a soul has travelled here from Mars in a hundred years. So how'd they get here in a month? No one knows.

Listen, here's what we do know. Sporian expansion only happens when we stop showing up. They don't want the rock, they want us. And as long as the G Council keeps sending in new blood, they'll stay here. The next
Good News Number 3. See all
those stars out there? There's over a centillian people out there, all of them living happy lives. See that muddy trench? That's where the Sporians are and because we're here, that's where they're going to stay. You are saving the Universe. You are a goddamn hero.

Now drink.

Sylvia Spruck Wrigley was born in Germany and spent her childhood in Los Angeles. She now splits her time between South Wales and Andalucia, two coastal regions with almost nothing in common. You can find out more about her at www. intrigue.co.uk. 